\title{
COMPENSATION AND WORK DISCIPLINE ON EMPLOYEE PERFORMANCE WITH JOB SATISFACTION AS INTERVENING
}

\author{
I Ketut R. Sudiarditha \\ sudiarditha@yahoo.com \\ Dewi Susita \\ Tri Mulyani Kartini \\ Fakulty of Economics, Universitas Negeri Jakarta \\ Jl. Rawamangun Muka, Jakarta 13220
}

received: 10/7/19; revised: 3/12/19; published: 31/12/19

\begin{abstract}
This study aims to determine the effect of compensation and work discipline on employee performance through job satisfaction as an intervening. This research conduct at PT. XD Sakti Indonesia. The population is employees belonging to grade 2 (non-staff); The sample was taken, 200 respondents. Primary data and analyzed using Structural Equation Model (SEM). The results showed that compensation and work discipline had a positive and significant effect on employee performance through job satisfaction as an intervening. The findings of this study prove that compensation and work discipline have a positive and significant effect on job satisfaction, which can further improve employee performance. The independence of employees in performing has not been able to show their ability according to their duties and responsibilities, which is caused by the lack of employee confidence.
\end{abstract}

Keywords: employee performance; compensation; work discipline; job satisfaction

\section{INTRODUCTION}

An established company aims to obtain maximum profit, intended so that the company can live sustainably. The establishment of a company is not limited to a specific time but is expected to live indefinitely. Therefore, the survival of the company will continue to be maintained by trying to get the maximum profit. If the company gets high profits and the survival of the company is expected to have an impact on the welfare of the broader community outside the company, and this is a management achievement in managing the company (Harjito \& Martono, 2010). For this reason, it is essential to evaluate the performance of a company for both internal and external purposes. For investors, the benefit of information about performance is to see whether investors will maintain investment in the company or look for other alternatives.

In measuring performance, it can see from one of the Human Resource Management (HR). The effort to develop HR is a continuous learning process, both from the HR itself and from its organization to be better than before. Building human beings as social creatures is emphasized on the dignity, human dignity, and obligation that is reflected in personality, physical and spiritual aspects; whereas as a development resource the emphasis is on psychological aspects such as compensation, work discipline and job satisfaction (Sudiyono \& Palupi, 2016).

Various employee performance studies that have been conducted by Nurcahyani \& Adnyani (2016) share indicators, including quality of work, the quantity of work, timeliness, effectiveness, and work commitment. While Juliarti et al. (2018), dividing indicators include: work quality, tenacity, and endurance, discipline and attendance, cooperation, work safety issues, job responsibilities, creative initiatives, in this study which is different from other studies focus on indicators of work quantity, quality of work, timeliness, effectiveness, and employee independence (Mathis \& Jackson, 2012); which is undoubtedly different used by Nurcahyani \& Adnyani in adding commitment; while Juliarti et al. work safety and responsibility; in this study it appears from differences in independence; this is more due to the point of view of the object of research.

PT. XD Sakti Indonesia is a joint venture between XD Group China and Central Cipta Murdaya which found in 2012. The scope of the first phase of this business produces various types of transformers from $70 \mathrm{kV}-500 \mathrm{kV}$ and Gas Insulated Switchgear (GIS), including sales, repairs, and after service selling. The performance appraisal, based on the employee's Key 
Performance Indicator (KPI) in 2017, shows that the level of employee performance with "Fair" results was $63.6 \%$ of the total of 242 employees. This cannot be said to be good because the company's target is at least above $50 \%$ of the total existing employees, whereas in reality, employees with a "Good" score are 32.2\% employees (Department of Human Resources of PT. XD Sakti Indonesia, 2018).

In general, PT. XD Sakti Indonesia provides compensation by the UMK Bekasi City 2018 standard, which is Rp. 3,837,939 the figure rose 8.71 percent from the Bekasi Regency UMK in 2017, which was Rp. 3,530,438, - (Department of Human Resources of PT. XD Sakti Indonesia, 2018). However, the demands on the cost of living of employees in line with rising prices of goods, especially the needs of nine essential commodities have not been felt to be able to meet the needs of themselves and decent family life. The company has its standards for determining compensation but also continues to benchmark with companies throughout the region and see market conditions.

Based on the percentage of employee absenteeism in 2017, it can conclude that the employee absentee rate is categorized high, especially from January to May 2017 , because it is above $3 \%$. Besides, late attendance on time both starting work in the morning and after lunch break still seems orderly, which reflects employee discipline is still low (Department of Human Resources PT. XD Sakti Indonesia, 2018).

These phenomena are also reflected in employee job satisfaction, which is a challenge given that employee performance will reflect job satisfaction that preceded it. For this reason, one of the indicators of satisfaction is low salary and benefits received by employees; even below the MSE is a problem of dilemma. Various studies have conducted that job satisfaction is one of the essential variables in creating the best performance for the company. This study aims to determine the effect of compensation and work discipline on employee performance with job satisfaction as an intervention.

For companies, compensation is significant because it reflects the organization's efforts to maintain and improve the welfare of its employees. Experience shows that inadequate compensation can reduce work performance, work motivation, and job satisfaction, and can even cause potential employees to leave the company. So it can be said that compensation will affect employee performance.

Compensation, according to Mangkunegara (2013), is something that is considered as comparable. In staffing, monetary gifts are compensation given to employees in appreciation of their services. Meanwhile, according to Simamora (2014), defining compensation includes financial rewards and intangible services as well as benefits received by employees as part of the employment relationship. Compensation is what is received by employees in exchange for their contribution to the organization. It was further said that one of the objectives of the compensation itself was motivation and performance because employees craved their performance correlated with the rewards obtained from the organization. Meanwhile, according to Hasibuan (2014), one of the objectives of giving compensation is job satisfaction; by repaying, the employee will be able to meet the physical needs, social status, and egoism to obtain job satisfaction from his position.

Types of compensation according to Mondy (2012), are: (1) Direct financial compensation: pay that a person receives in the form of wage, salaries, commission, and bonuses, (2) Indirect financial compensation (benefits): all financial rewards that are not included in direct compensation, such as paid vacation, sick leave, holidays, and medical insurance, (3) non financial compensation: satisfaction that a person receives from the job itself or from the psychological and physical environment in which the person works. Precisely, according to Simamora (2014), indicators to measure employee compensation include salary/ wages, incentives, benefits, facilities.

Based on several opinions expressed by experts, it can be synthesized that compensation is all forms of payment provided by the company to employees as compensation for the implementation of duties or contributions of employees to the company, including indicators of direct financial compensation (salary, incentives) and indirect financial compensation (benefits, facilities).

One aspect of the strength of Human Resources (HR) can be reflected in the attitude and behavior of the discipline because it has a substantial impact on an organization to achieve success in pursuing planned goals. Afandi (2016) said that work discipline is a rule or order made by the management of an organization authorized by the capital owner or the board of commissioners, agreed by the union and known to the labor department so that people who are members of the organization are subject to the procedure orderly order is happy, so that it is created and formed through a process of a series of behaviors that demonstrate the value of obedience, obedience, order, and order. Intended is a form of obedience to the rules, both written and unwritten, that have been determined. While according to Busro (2018), work discipline is a mental attitude of a person or group who always wishes to obey or follow all the rules that have been determined. The discipline that grows from an employee will create his satisfaction (Hasibuan, 2014). This opinion confirms that discipline is an essential factor in the development of an employee's personality characteristics such as responsibility, confidence, perseverance in working, and self-control and can maintain and develop appropriate behavior at work and ultimately can improve employee performance. 
In measuring work discipline, Hasibuan (2004) divides into several indicators, namely: timely attendance, timeliness of completing work, obeying work regulations, carrying out work procedures, and using office equipment properly. This opinion is almost the same as said by Veithzal (2005) that work discipline has some of these indicators include: attendance, observance of work regulations, compliance with work standards, level of alertness, and ethical work.Based on some of the opinions above, work discipline can be synthesized as an effort by company management to implement regulations or policies that have been made to be fulfilled by every employee without exception, including indicators: timely attendance, accuracy in completing work, obeying work rules, carrying out work procedures, using office equipment, observance of work standards, alertness levels, and ethical work.

Job satisfaction is essentially an individual thing; each person will have a level of satisfaction that is not the same as the value system that applies to him. According to Handoko (2014), job satisfaction is someone's pleasant or unpleasant emotional state in which employees do their work. Almost the same said Badriyah (2015), job satisfaction is the attitude or feeling of employees towards the pleasant or unpleasant aspects of the work by each worker. Another case with Hasibuan (2014) says that job satisfaction is an emotional attitude that is fun and loves work. Every individual who works in an organization naturally expects to get everything that is beneficial and beneficial to himself personally. Employees' views of the conditions of the work environment and feelings of satisfaction or dissatisfaction with these conditions will affect their behavior at work. Robbins \& Judge (2013) argues that job satisfaction is a positive feeling about one's work that is the result of evaluating its characteristics.

Employees feel satisfied and enjoy their work because they get praise for their work, placement, treatment, equipment, and right working environment. Employees who prefer to enjoy job satisfaction at work will prioritize their work more than repayments even though remuneration is essential so that employee performance will increase. In general, job satisfaction, according to experts, uses indicators: work itself, supervision, workers, promotion, pay (Luthans, 2006; Rivai, 2013). Based on the description of several experts above, it can be synthesized that job satisfaction is the employee's feeling of pride from his assessment of his success in completing the overall task to satisfy his needs that can be seen from salary, work itself, supervision, promotion opportunities, coworkers.

According to Rivai (2013), the notion of performance or work performance is the result or overall level of success of a person during a specific period in carrying out the task compared to various possibilities, such as work standards, targets or targets or predetermined criteria that have been mutually agreed upon. Several factors can affect performance, namely: ability and expertise, knowledge, work design, personality, work motivation, leadership, leadership style, job satisfaction, work relationships, commitment, work discipline (Kasmir, 2016). Meanwhile, according to Wirawan (2015) that internal factors that affect performance include: work ethic, work discipline, and job satisfaction. In this case, which affects the performance of employees, the focus of the compensation variable, work discipline, and job satisfaction are intervening variables.

In measuring employee performance by Mathis \& Jackson (2012) that the elements are: quantity of work, quality of work, timeliness, effectiveness, attendance, and independence. While Juliarti et al. (2018), dividing indicators include: work quality, tenacity, and endurance, discipline and attendance, cooperation, work safety issues, job responsibilities, creative initiatives, in this study the indicators used include: work quantity, work quality, timeliness, effectiveness, and employee independence.

Based on the opinion of the experts mentioned above, it can be synthesized that performance is the behavior or activities of a person in carrying out his responsibilities for all tasks assigned by the company to achieve goals, including indicators: work quantity, work quality, timeliness, effectiveness, and employee independence.

Hypothesis: H1: Compensation has a positive effect on employee performance. $\mathrm{H} 2$ : Work discipline has a positive effect on employee performance. H3: Compensation has a positive effect on employee job satisfaction. H4: Work discipline has a positive effect on employee job satisfaction. H5: Job satisfaction has a positive effect on employee performance. H6: Compensation has a positive effect on employee performance through job satisfaction as intervening $\mathrm{H} 7$ : Work discipline has a positive effect on employee performance through job satisfaction as intervening.

\section{METHOD}

This research uses a quantitative approach with an explanatory or causal design that aims to explain how one variable influences or is responsible for changes in other variables. This research is cross-sectional, which is a type of research that collects information only once in a specific time to the sample. This research was conducted to determine the effect of compensation and work discipline on employee performance with job satisfaction as an intervening study at PT XD Sakti Indonesia.

According to the focus of the study, the population in this study were all employees of PT. XD Sakti Indonesia, which is classified as grade 2 (non-staff); positioned in this grade demand demanding minimum educational requirements for senior high school +2 years experience; or Elementary School/Junior High 
School $(\mathrm{SD} / \mathrm{SLTP})+4$ years experience. Based on various studies that have been carried out on various estimation methods, one of the conclusions is that the minimum sample size needed to reduce bias in all types of SEM estimates is 200 (Loehlin, 1998) - in this study, using a sample of 200 respondents based on the returned questionnaire by considering the completeness of the required data. Data collected from primary data using a Likert scale questionnaire, namely by giving a written statement, then processed using the Structural Equation Model (SEM).

\section{RESULTS}

Hypothesis testing in this study was done by looking at the critical value (CR) at a $5 \%$ confidence level or an error of 1.96; the CR value received was higher than 1.96. The results of testing in this study can be seen in Figure 2.

Based on the results of testing the model, it can be seen that the compensation variable on employee performance has a t-value of 2.48>1.96; means H1 is accepted. Work discipline on employee performance has t-value of 3.62> 1.96; it means $\mathrm{H} 2$ is received. Compensation for job satisfaction produces t-value of 3.81 > 1.96; it means H3 is received. Work discipline on job satisfaction produces t-value of 5.55> 1.96; it means H4 is received. Furthermore, job satisfaction with performance produces a t-value of $1.99>1.96$; it means $\mathrm{H} 5$ is received.

Based on these results, it can be concluded that compensation and work discipline directly influence job satisfaction and job performance. The effect of compensation on performance with job satisfaction as an intervening variable (Table 1) from the acquisition of indirect effects obtained a regression coefficient of 0.03 and t-value of 1.99> 1.96; thus H6 is accepted; it means that compensation has a significant indirect effect on performance through job satisfaction. While work discipline on performance with job satisfaction as an intervening variable from the acquisition of indirect effects obtained a regression coefficient value of 0.05 and a t-value of $1.96 \geq 1.96$; thus $\mathrm{H} 7$ is accepted; it means that work discipline has a significant indirect effect on performance through job satisfaction.

\section{DISCUSSION}

The first hypothesis testing results show that the hypothesis is accepted because it has a positive estimate value of 0.22 and a t-value of $2.48>1.96$. These results indicate that compensation has a positive effect on employee performance at PT. XD Sakti Indonesia; it means that the better the compensation was given, the more the employee's performance increases.

The positive effect of compensation on employee performance is in line with the opinions of several experts, including Simamora (2014), which states that one of the goals of compensation is motivation and performance because employees crave their performance correlated with the rewards obtained from the organization. Also, Handoko (2014) states that compensation is a way for the personnel department to improve work performance, motivation, and employee job satisfaction. This can be interpreted that in addition to functioning as remuneration or reward, according to him, compensation is one of the ways used by companies to increase employee motivation and also increase employee job satisfaction, which will ultimately affect employee performance improvement.

The results of compensation research on employee performance also support the results of previous studies conducted by Sopiah (2013), Damayanti \& Sumaryati (2013), Umar (2014), Nurcahyani \& Adnyani (2016), Suryadharma et al. (2016), Juliarti et al. (2018) the conclusion of his research results shows that compensation has a positive and significant effect on employee performance. However, it is different from the results of the study of Shahab \& Nisa (2014) and Rachmawati \& Mauludin (2018) the research results conclude that incentives do not significantly influence performance.

PT. XD Sakti Indonesia in applying compensation can be seen from the elements of salary and incentives. Implementation of the salary element has been attempted to meet the district minimum wage, and only a small portion has not been met, especially employees with probation status. While the incentive element is only for employees who have achievements by applicable company regulations; therefore, employees who do not meet specific criteria assume incentives cannot trigger employee performance improvement. The compensation has been managed well by the management and is enough to pay attention to all employees because most employees still see compensation as one of the variables that can improve employee performance.

The second hypothesis testing results show that the hypothesis is accepted because it has a positive estimate value of 0.33 and a t-value of $3.52>1.96$. These results indicate that work discipline has a positive influence on employee performance at PT. XD Sakti Indonesia; it means that the better the work discipline, the better the performance of the employees.

The results of this study support the statement of Simamora (2014) Good work discipline can be used as a habit of behavior to be carried out sustainably as it is the responsibility of employees. Disciplinary action can also help employees to be more productive, thereby benefiting in the long run. So that improving employee performance can be rewarded with promotions and salary increases. Practical disciplinary actions can make employees improve performance, which ultimately results in achievement for individuals (Awadh \& Alyahya, 2013). 
The results of this work discipline study on employee performance support some of the results of previous studies conducted by: Shahab \& Nisa (2014), Mardiono \& Supriyatin (2014), Sahanggamu \& Mandey (2015), and Andjarwati et al. (2019) that the conclusion of his research shows that work discipline has a positive and significant effect on employee performance.

PT. XD Sakti Indonesia has implemented friendly work discipline in handling every problem; this shows that work discipline has been implemented well by the management and is transparent in carrying out a punishment system for employees who make mistakes; it is clear that good work discipline is one of the variables that can improve employee performance.

The third hypothesis testing results indicate that the hypothesis is accepted because it has a positive estimate value of 0.32 and a t-value of 3.81>1.96. These results indicate that compensation has a positive effect on job satisfaction at PT. XD Sakti Indonesia; it means that the better the compensation received by employees, the better the job satisfaction of employees. The results of this study support the statement of Islam et al. (2012) said that financial reward is one of the factors that result in job satisfaction. In addition, Hasibuan (2014) states that employee job satisfaction is influenced by factors such as fair and proper remuneration, proper placement and in accordance with expertise, severity of work, work environment and environment, equipment that supports work performance, leadership attitude in his leadership, and the nature of the work is monotonous or not.

The results of compensation research on job satisfaction support the results of previous studies conducted by: Islam et. al. (2012), Indrawan \& Dewi (2014), Kurniawan (2016), Retnoningsih et al. (2016), and Juliarti et al. (2018) in the conclusion of the results of his study showed that compensation has a positive and significant effect on job satisfaction. This means that if employees get compensation that can reflect fairness and worth, employees can feel satisfaction in carrying out their duties according to their duties and responsibilities.

PT. XD Sakti Indonesia in applying compensation has tried to pay attention to district minimum wages; in practice, there are still some unfulfilled employees who are more due to the probation period not being adequately fulfilled. Based on this data, it still appears that some employees have not yet received the district minimum wage. Behind that, some things the management has paid attention to other benefits such as vacation facilities that are expected to create employee satisfaction. Employee compensation is being made and continues to be improved so that the company can attract potential employees and also retain employees who have excellent abilities because, in recent years, the compensation factor has become one of the turnovers that are quite high due to employee dissatisfaction with the company.
The fourth hypothesis testing results indicate that the hypothesis is accepted because it has a positive estimate value of 0.47 and a t-value of 5.55> 1.96. These results indicate that work discipline has a positive and significant effect on job satisfaction at PT. XD Sakti Indonesia, meaning that the better the work discipline, the better the job satisfaction of employees.

Demak \& Pengemanan (2014) said that disciplinary procedures are essential tools for realizing management success, such as labor stability, labor turnover, and increasing effective productivity. If an employee can make all the rules that have been prepared by the company well and show a positive response, then psychologically, it will have a positive effect on increasing job satisfaction. Therefore, disciplinary procedures must be adequately enforced, namely by providing disciplinary sanctions that must be applied objectively so that they can be accepted by all employees.

In addition, work discipline has an influence on job satisfaction; for that the management should improve employee work discipline because according to Rivai (2013) discipline is a tool used by managers to communicate with employees, so they are willing to change a behavior and as an effort to increase awareness and willingness to obey a company's rules and norms social norms that apply. Furthermore, the behavior is by individual attitudes that type of attitude is influenced by satisfaction, work involvement, and commitment to the organization. Employee involvement in the organization is an attitude that must be shown that employees participate in making or thinking about work planning by having a high commitment to work. Thus employee discipline is a healthy attitude that must be appropriate within an organization as a whole so that it forms a positive attitude that is widely adopted, firm, and consistent by its members or employees to achieve organizational goals.

The results of work discipline studies on employee job satisfaction also support the results of previous studies conducted by: Demak \& Pangemanan (2014), Mardiono \& Supriyatin (2014), Duha (2018), and Andjarwati et al. (2019) in the conclusion of his research proves that work discipline has a positive and significant effect on job satisfaction.

PT. XD Sakti Indonesia in implementing work discipline has implemented well by management and is firm in implementing company regulations to its employees so that employees comply with the rules and regulations that apply in the company. Awareness of employee's work discipline is essential to be obeyed by all employees; this has been successfully created by the reduction in violations committed by employees. Seeing the condition that is getting better; all elements in the company feel that satisfaction is increasingly created, thus work discipline that has been felt to be getting better indicates that job satisfaction is also increasing. 
The fifth hypothesis testing results indicate that the hypothesis is accepted because it has a positive estimate value of 0.19 and a t-value of $1.99>1.96$. These results indicate that job satisfaction has a positive effect on employee performance at PT. XD Sakti Indonesia, namely the better job satisfaction provided, the better the performance of employees.

The positive influence of job satisfaction on performance is in line with the opinions of several experts, including Hasibuan (2014), which states that job satisfaction is an emotional attitude that is fun and loves work. This attitude is reflected by work morale, discipline, and work performance. Job satisfaction is enjoyed at work, outside of work, and a combination of inside and outside work, so employees who get job satisfaction tend to have excellent performance. Also, Robbins \& Judge (2013) states that in terms of employees feeling satisfied and enjoying their work because they get praise for their work, placement, treatment, equipment, and pleasant working environment, employees who prefer to enjoy job satisfaction at work will prioritize their work rather than retribution even though retribution is essential, so employee performance will improve.

The results of the job satisfaction research on employee performance also support the results of previous studies conducted by: Yusuf et al. (2012), Sopiah (2013), Gayathiri et al. (2013), Mardiono \& Supriyatin (2014), Shahab \& Nisa (2014), Umar (2014), Arifin (2015), Suryadharma et al. (2016), and Juliarti et al. (2018) in the conclusion of the results of his study showed that job satisfaction has a positive and significant effect on employee performance. PT. XD Sakti Indonesia, in creating job satisfaction, always pays attention to various things that are needed by employees, such as a conducive work environment to be one of the essential things to be considered by the management. This can trigger performance improvements because employees get satisfaction in their work; whether the satisfaction comes from existing work or the work environment, and based on observations in the field it appears that employee performance has improved when employees get satisfaction, where the source of satisfaction currently comes from friendly supervision but instead applies the element of trust and working environment conditions comfortable and a high sense of kinship between employees and management.

The sixth hypothesis testing results indicate that the hypothesis is accepted because it has a positive estimate value of 0.06 and a t-value of $1.99>1.96$. These results indicate that compensation has a significant indirect effect on employee performance through job satisfaction at PT. XD Sakti Indonesia, namely the better compensation provided by the company to employees, the more job satisfaction of employees increases and can further improve employee performance.

PT. XD Sakti Indonesia, in implementing financial and non-financial compensation, can trigger employee performance to produce well. Because for employees, compensation is a way to meet the needs of self and family life. The compensation system can be the beginning and end of an employee's job satisfaction to improve employee performance. Compensation done well can cause a sense of pleasure or satisfaction with their work in carrying out their duties and obligations as employees. These feelings will encourage employees to improve their performance as desired by the company. These findings indicate that the hypothesis proposed proved job satisfaction is a mediator of the effect of compensation on employee performance. Indirectly giving more significant influence than directly remembering to further improve performance in advance employee job satisfaction is created.

The seventh hypothesis test results show that the hypothesis is accepted because it has a positive estimate value of 0.05 and a t-value of $1.96 \pm 1.96$. These results indicate that work discipline has a significant indirect effect on work performance through job satisfaction at PT. XD Sakti Indonesia, namely the better work discipline that can be applied by employees, the more job satisfaction of employees increases and can further improve employee performance.

PT. XD Sakti Indonesia can trigger employee performance because discipline for employees is an obligation that must be obeyed according to company rules while being an employee. The implementation of discipline is more directed at employee awareness, not to feel forced. This allows employees to implement it wholeheartedly, even though their superiors supervise not all. The success that is created from work discipline with employee self-awareness can create employee job satisfaction itself. These findings indicate that the proposed hypothesis is proven that job satisfaction is a mediator of the effect of work discipline on employee performance. Indirectly giving more significant influence than directly remembering to further improve performance in advance employee job satisfaction is created.

\section{CONCLUSION}

Based on the results of the analysis, several conclusions can be drawn: First, compensation has a positive and significant effect on the performance of the employees of PT. XD Sakti Indonesia. This shows that if the company provides excellent compensation and pay attention to employee welfare, it will improve employee performance and can increase the perception that the company provides better support for its employees. Second, work discipline has a positive and significant effect on the performance of the employees of PT. XD Sakti Indonesia. This shows that the better the employees apply their work discipline and comply with the company's rules/regulations, the more the employee's performance increases and can increase the perception that the company provides fairness and better 
support for its employees. Third, job satisfaction has a positive and significant effect on the performance of the employees of PT. XD Sakti Indonesia. This shows that the better the company provides job satisfaction to employees, it will improve employee performance and can increase the perception that the company provides better support to its employees. Fourth, compensation has a positive and significant effect on job satisfaction of employees of PT. XD Sakti Indonesia. This shows that if the company provides compensation and pay attention to the welfare of its employees, it will increase employee job satisfaction. The fifth work discipline has a positive and significant effect on job satisfaction of employees of PT. XD Sakti Indonesia. This shows that the better employees implement work discipline and comply with company regulations, the better job satisfaction of employees. Sixth, compensation has a positive and significant effect on employee performance by mediating job satisfaction of PT. XD Sakti Indonesia. This shows that the better the compensation, the more job satisfaction increases and can further improve employee performance. Seventh, work discipline has a positive and significant effect on employee performance by mediating job satisfaction of PT. XD Sakti Indonesia. This shows that the better employees apply work discipline, the more job satisfaction increases and can further increase employee performance.

\section{REFERENCES}

Afandi, P., 2016. Concept \& Indicator Human Resources Management for Management Research. Deepublish.

Andjarwati, T., Setiono, B.A., Susilo, K.E., Budiarti, E., Sustiyatik, E., Audah, A.K. and Winarno, A.F., 2019. The Effect Of Osha, Work Environment And Work Discipline On Employee Satisfaction And Employee Performance. Archives of Business Research (ABR), 7(11).

Arifin, H.M., 2015. The Influence of Competence, Motivation, and Organisational Culture to High School Teacher Job Satisfaction and Performance. International Education Studies, 8(1), pp.38-45.

Awadh, A.M. and Alyahya, M.S., 2013. Impact of organizational culture on employee performance. International review of management and business research, 2(1), p.168.

Badriyah, M., 2015. Manajemen Sumber Daya Manusia. Bandung: CV Pustaka Setia.

Busro, M., 2018. Teori-Teori Manajemen Sumber Daya Manusia. Prenada Media.

Damayanti, A.P. and Sumaryati, S., 2013. Pengaruh Kompensasi dan Motivasi Kerja Terhadap Kinerja Karyawan Perusahaan Daerah Air Minum (PDAM) Surakarta. Jupe-Jurnal Pendidikan Ekonomi, 2(1).

Demak, J.R.K. and Pangemanan, S.S., 2014. Employee Discipline And Attitude To Job Satisfaction In
Sekretariat Daerah Kabupaten Minahasa. Jurnal EMBA: Jurnal Riset Ekonomi, Manajemen, Bisnis dan Akuntansi, 2(3).

Duha, T., 2018. Lecturer Job Satisfaction Affected By Discipline And Motivation Mediated By Organizational Commitment. Jurnal Aplikasi Manajemen, 16(2), pp.300-308.

Gayathiri, R., Ramakrishnan, L., Babatunde, S.A., Banerjee, A. and Islam, M.Z., 2013. Quality of work life-Linkage with job satisfaction and performance. International Journal of Business and Management Invention, 2(1), pp.1-8.

Handoko, T. Hani. 2014. Manajemen Personalia dan Sumber Daya Manusia, Edisi Ke-2. Yogyakarta: $B P F E$.

Harjito, A. \& Martono. 2011. Manajemen Keuangan. Edisi Kedua, Cetakan Pertama. Yogyakarta: Penerbit Ekonisia.

Hasibuan, M. S. 2014. Manajemen Sumber Daya Manusia (revisi). Jakarta: Bumi Aksara.

Human Resources Department PT. XD Sakti Indonesia, 2018.

Indrawan, D. C., \& Dewi, A. S. K. 2014. Pengaruh Kompensasi, Kepemimpinan, dan Lingkungan Kerja Fisik terhadap Kepuasan Kerja Karyawan PT. Cargo Asas International, Denpasar. E-Jurnal Manajemen, 3(6).

Islam, T., Ahmad, Z., Ahmed, I., Ahmad, A., Saeed, M. and Muhammad, S.K., 2012. Does compensation and demographical variable influence on teachers commitment and job satisfaction? a study of university of the Punjab, Pakistan. International Journal of Business and Management, 7(4), p.35.

Juliarti, P.A.D., Agung, A.A.P. and Sudja, I.N., 2018. Effect of Compensation and Work Environment on Employee Performance with Employee Job Satisfaction as an Intervening Variable. International Journal of Contemporary Research and Review, 9(03), pp.20553-20562.

Kasmir, D. 2016. Manajemen Sumber Daya Manusia (Teori dan Praktek). Jakarta: Rajawali Pers.

Kurniawan, D. 2016. Pengaruh Kompensasi dan Keselamatan dan Kesehatan Kerja (K3) terhadap Kepuasan Kerja pada Karyawan PT. Cahaya Samtraco Utama Samarinda. Ejournal Psikologi. Fisip-Unmul. Ac. Id, 2477-2674.

Loehlin, J.C. 1998. Latent Variabel Models: An Introduction to Factor, Path, and Structural Analysis. Lawrence Erlbaum Associates, Mahwah, NJ.

Luthans, F. 2006. Perilaku Organisasi, Alih Bahasa, V.A. Yuwono, dkk. Yogyakaarta: PT. Andi.

Mangkunegara, A. P. 2013. Manajemen Sumber Daya Manusia: Cetakan Kesebelas. Bandung: PT. Remaja Rosdakarya.

Mardiono, D. \& Supriyatin. 2014. Pengaruh Motivasi dan Disiplin Kerja terhadap Kepuasan Kerja Karyawan. Jurnal Ilmu dan Riset Manajemen, 3 (3). 
Mathis, R. L., \& Jackson, J. H. 2012. Manajemen Sumber Daya Manusia Buku 2 Alih Bahasa Jimmy Sadeli. Jakarta: Salemba Empat.

Mondy, Wayne R. 2012. Human Resources Management. Twelfth Edition. England: Pearson Education Limited.

Nurcahyani, N. M., \& Adnyani, I. D. 2016. Pengaruh Kompensasi dan Motivasi terhadap Kinerja Karyawan dengan Kepuasan Kerja Sebagai Variabel Intervening. E-Jurnal Manajemen Universitas Udayana, 5(1), 500-535.

Rachmawati, D. and Mauludin, H., 2018. The Effect of Work Discipline and Job Involvement on the Performance with Incentive as Intervening Variable. International Journal of Business and Management Invention (IJBMI), 7(8).

Retnoningsih, T., Sunuharjo, B.S. and Ruhana, I., 2016. Pengaruh Kompensasi Terhadap Kepuasan Kerja Dan Kinerja Karyawan (Studi Pada Karyawan PT Pln (Persero) Distribusi Jawa Timur Area Malang). Jurnal Administrasi Bisnis, 35(2), pp.53-59.

Rivai, V. 2013. Manajemen Sumber Daya Manusia untuk Perusahaan: Dari Teori ke Praktik. Jakarta: Rajawali Pers.

Robbins, S. P., \& Judge, T. A. 2013. Organizational Behavior. 15th Edition. New Jersey: Pearson Education, Inc.

Sahanggamu, P. M., \& Mandey, S. L. 2015. Pengaruh Pelatihan Kerja, Motivasi, dan Disiplin Kerja terhadap Kinerja Karyawan pada PT. Bank Perkreditan Rakyat Dana Raya. Jurnal EMBA: Jurnal Riset Ekonomi, Manajemen, Bisnis dan Akuntansi, 2(4), 514-523.

Table 1. Indirect Effects of KSI on ETA Pathways Diagram

\begin{tabular}{lcc}
\hline & Compensation & Work discipline \\
\hline Employee performance & 0.06 & 0.09 \\
Job satisfaction & $(0.03)$ & $(0.05)$ \\
\hline & 1.99 & 1.96 \\
\hline
\end{tabular}

Source: data processed, 2018
Shahab, M. A., \& Nisa, I. 2014. The Influence of Leadership and Work Attitudes Toward Job Satisfaction and Performance of Employee. International Journal of Managerial Studies and Research, 2(5), 69-77.

Simamora, H. 2014. Manajemen Sumber Daya Manusia. Yogyakarta: Bagian Penerbitan Sekolah Tinggi Ilmu Ekonomi YKPN.

Sopiah, S. 2013. The Effect of Compensation Toward Job Satisfaction and Job Performance of Outsourcing Employees of Syariah Banks in Malang, Indonesia. Int. J. Learn. Dev, 3(2).

Sudiyono, L. \& Palupi Y. 2016. Ilmu Sosial Dasar. Yogyakarta: Kaliwangi Offset.

Suryadharma, I.M.A., Riana, I.G. and Sintaasih, D.K., 2016. Pengaruh kepemimpinan dan kompensasi terhadap Kepuasan kerja dan kinerja karyawan (studi pada PT. BPR Sri Artha Lestari Denpasar). E-Jurnal Ekonomi dan Bisnis Universitas Udayana.

Umar, A. 2014. Effect of Wages, Work Motivation and Job Satisfaction on Workers' Performance in Manufacturing Industry in Makassar City. European Journal of Business and Management, 6(5), 75-88.

Veithzal, R. and Basri, A.F.M., 2005. Performance Appraisal. Jakarta. PT Raja Grafindo Persada.

Wirawan. 2015. Manajemen Sumber Daya Manusia Indonesia. Jakarta: PT Raja Grafindo Persada.

Yusuf, R.M., Eliyana, A. and Sari, O.N., 2012. The influence of occupational safety and health on performance with job satisfaction as intervening variables (Study on the production employees in PT. Mahakarya Rotanindo, Gresik). American Journal of Economics, 6, pp.136-140.

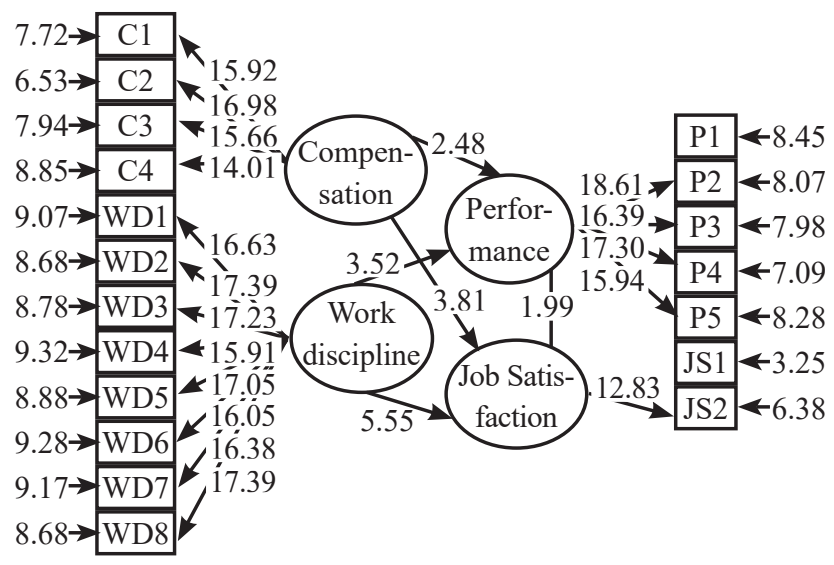

Chi-square $=168.62, \mathrm{df}=145, \mathrm{p}$-value $=0.8746, \mathrm{RMSEA}=0.028$

Figure 1. Path Diagram of Structural Model Test Results (t-Value) 